\title{
Research Paper Ningnanmycin inhibits tobacco mosaic virus virulence by binding directly to its coat protein discs
}

\author{
Xiangyang Li ${ }^{1}$, Gefei Hao ${ }^{2}$, Qingmin Wang ${ }^{3}$, Zhuo Chen ${ }^{1}$, Yan Ding ${ }^{1}$, Lu Yu ${ }^{1}$, Deyu \\ $\mathrm{Hu}^{1}$ and Baoan Song ${ }^{1}$ \\ ${ }^{1}$ State Key Laboratory Breeding Base of Green Pesticide and Agricultural Bioengineering, Key Laboratory of Green Pesticide \\ and Agricultural Bioengineering, Ministry of Education, Guizhou University, Guiyang 550025, P. R. China \\ ${ }^{2}$ Key Laboratory of Pesticide and Chemical Biology of Ministry of Education, College of Chemistry, Central China Normal \\ University, Wuhan 430079, P. R. China \\ ${ }^{3}$ State Key Laboratory of Elemento-Organic Chemistry, Nankai University, Tianjin 300071, P. R. China \\ Correspondence to: Zhuo Chen, email: gychenzhuo@aliyun.com
}

Baoan Song, email: basong@gzu.edu.cn

Keywords: ningnanmycin, TMV CP, binding analysis, interaction studies

Received: April 26, $2017 \quad$ Accepted: June 29, $2017 \quad$ Published: July 19, 2017

Copyright: Li et al. This is an open-access article distributed under the terms of the Creative Commons Attribution License 3.0 (CC BY 3.0), which permits unrestricted use, distribution, and reproduction in any medium, provided the original author and source are credited.

\section{ABSTRACT}

Tobacco mosaic virus (TMV) causes severe plant diseases worldwide; however, effective antiviral agents for controlling TMV infections are not available. This lack of effective antiviral agents is mainly due to the poor understanding of potential targets associated with TMV infections. During infection, the coat protein (CP), which is delivered by viral particles into susceptible host cells, provides protection for viral RNA. Here, we found that Ningnanmycin (NNM), a commercially used plant antibacterial agent, inhibits the assembly of the CP by directly binding several residues. These interactions cause the disassembly of the CP from discs into monomers, leading to an almost complete loss of pathogenicity. Substitutions in the involved binding residues resulted in mutants that were significantly less sensitive to NNM. Thus, targeting the binding of viral CPs through small molecular agents offers an effective strategy to study the mechanism of NNM.

\section{INTRODUCTION}

Plant viral diseases cause significant losses in agriculture and low-cost agents capable of effectively controlling such diseases are in great need. Antiviral compounds that target RNA and chemicals that aim at stimulating plant disease resistance have received intensive attention in recent years $[1,2]$. However, few studies have focused on the use of viral coat proteins (CPs) and their assembly as potential targets for infection control [3]. Tobacco mosaic virus (TMV) causes diseases in a wide variety of economically important plants, yet few effective anti-TMV agents are available [4, 5]. Furthermore, the molecular mechanism of action for the few existing antiTMV agents remain unclear. There is thus a great need to identify novel targets for the development of effective anti-TMV drugs $[1-3,6]$.
The CP forms aggregate discs that interact with the newly synthesized positive sense TMV RNA to assemble progeny virions. It also facilitates the long-distance movement of the virus [7]. The aggregation of CP initiated by RNA recognition plays an important role in viral assembly, initiation and elongation. The CP is essential in maintaining and protecting the RNA genome [8]. In TMV viral particles, electrostatic interactions by residues Arg90, Arg92, Arg112 and Arg113 among monomers and with the RNA phosphate backbone are important for viral stability [9-12]. A mutational analysis revealed that residues Glu95, Glu97, Glu106, Asp109 and Asp116 [13], and the contact pair Glu50 and Asp77 in the CP were involved in the disassembly of viral particles [14]. In the absence of TMV RNA, the CP can form aggregate discs in vitro through physical regulation $[15,16]$. The CP also affects the display of viral and host responses [17], 
and regulates the production of movement proteins and virus replication complexes during infection [18, 19]. In addition, CP-mediated resistance has been demonstrated using transgenic CP and hairpin RNA technology [20, 21].

The recombinant TMV CP expressed in Escherichia coli can assemble into discs using a hydrogen bonding network and salt bridges [6, 22, 23]. In conjunction with genomic RNA, the CP aggregates formed viral particles in vitro through hydrophobic and electrostatic interactions. The TMV particles artificially reconstructed from recombinant $\mathrm{CP}$ retain their self-assembly function [6], providing a system to identify and evaluate small molecules capable of inhibiting the CP's functions.

Ningnanmycin (NNM) is a commonly used antimicrobial agent that exhibits an antiviral activity against TMV [24]. This compound is able to inhibit CP polymerization in vitro [24]. However, the mechanisms of such inhibition, as well as its anti-TMV effects, remain elusive [24]. Here, we found that NNM interferes with the assembly of the TMV CP four-layer aggregate discs. Using computational simulations and a mutational analysis, we identified the residues on the TMV CP that are directly involved in the NNM interaction. The study also establishes a useful model system that allows the rapid screening of antiviral agents against viral infections.

\section{RESULTS}

\section{Identifying that NNM binds to TMV CP and TMV RNA}

Recombinant CP four-layer aggregate discs were formed in phosphate buffer at $20^{\circ} \mathrm{C}$ for more than $12 \mathrm{~h}$. They were collected as target proteins and TMV RNA was isolated from infected-TMV tobacco leaves. The TMV RNA was added to the recombinant CP four-layer aggregate discs to form TMV particles. The recombinant $\mathrm{CP}$ exhibited an activity similar to its native form in the construction of infectious viral particles [6]. We studied the interactions between NNM and TMV particles, NNM and CP discs, and TMV RNA and CP discs using microscale thermophoresis (MST) (Figure 1A). The NNM bound to TMV particles with a dissociation constant $(\mathrm{Kd})$ of 25.8-52.3 $\mu \mathrm{M}$ (Figure 1B and Supplementary Table 1), the NNM bound to CP discs with a Kd of 1.10-3.96 $\mu \mathrm{M}$ (Figure 1C and Supplemental Table 1), and the TMV RNA bound to $\mathrm{CP}$ discs with a $\mathrm{Kd}$ of $144.8-207.3 \mu \mathrm{M}$ from $20^{\circ} \mathrm{C}$ to $30^{\circ} \mathrm{C}$ (Figure 1D and Supplemental Table 1). The affinity between NNM and CP discs or TMV particles was greater than the affinity between TMV RNA and CP discs. Additionally, we studied the interactions between NNM and TMV RNA using isothermal titration calorimetry (ITC) (Figure 1E). The NNM bound to TMV RNA with a $\mathrm{Kd}$ of $16.5 \mu \mathrm{M}$ (Figure 1E and Supplemental Table 1). The affinity between NNM and CP discs was greater than the affinity between NNM and TMV RNA. Thus, the target of NNM is main CP discs. Because TMV particles are composed of TMV CP discs and TMV RNA, and TMV $\mathrm{CP}$ discs are stabilized by numerous protein-protein salt bridges and hydrogen-bonding networks among protein layers, we reasoned that NNM bound CP with a high affinity through similar chemical bonds by competing for the residues contributing to disc stability. Thus, it may be possible to destabilize the CP complex and decrease the virulence.

\section{NNM induces the disassembly of TMV CP dises}

NNM was capable of disrupting the oligomeric structure of recombinant CPs of TMV. Briefly, recombinant TMV CP was allowed to form functional aggregates. After adding the test compounds, the protein samples were examined by size-exclusion chromatography (SEC) and transmission electron microscopy (TEM) (Figure 2). We further analyzed the effects of these compounds on the biochemical properties of this CP. As expected, initially all recombinant TMV CP was eluted as discs (Figures 2A-B). When NNM was added at a ratio of 1:5 (CP four-layer aggregate discs:NNM molecules) to the disc solution, a significant portion $(60 \%)$ of the discs disassembled into monomeric proteins (Figure 2C). The induction of disc disassembly by NNM was dose-dependent. Increasing the amount of NNM led to a larger extent of disassembly. When the ratio between TMV CP and NNM reached 1:20, the discs were completely disassembled into monomeric proteins (Figures 2D-E). Additionally, the wild type (wt) CP four-layer aggregate discs (isolated from TMV particles) were used as targets, to test the interaction between the wt CP four-layer aggregate discs and NNM. When the ratio between the wt $\mathrm{CP}$ four-layer aggregate discs and NNM molecules reached 1:20, the wt CP fourlayer aggregate discs were completely disassembled into monomeric proteins (Supplementary Figure 1). The affinities between NNM-CP monomers and CP-CP monomers were evaluated, and the results implied that NNM have a strong affinity of $18.6 \mu \mathrm{M}$, leading to CP disc disassembly (the $\mathrm{Kd}$ of $\mathrm{CP}-\mathrm{CP}$ was $234.2 \mu \mathrm{M}$ ) (Figures $3 \mathrm{~A}-3 \mathrm{C}$ ). We thus deduced that NNM disrupts the uniform multimeric structure of the CP.

We next determined the affinity between $\mathrm{CP}$ and NNM using two other independent methods, fluorescence spectrum and ITC. Fluorescence spectrum measurements showed that the NNM bound to TMV CP discs with a Kd of $1.87 \mu \mathrm{M}$ (Figure 4A and Supplementary Table 2). The analysis by ITC revealed that one CP disc interacted with 39 to 41 NNM molecules, and NNM bound to CP discs with a $\mathrm{Kd}$ of $6.25 \mu \mathrm{M}$ (Figure 4B and Supplementary Table 2). The titration data $(\Delta \mathrm{H}=17200 \mathrm{cal} / \mathrm{mol}$ and $\Delta \mathrm{S}=-79.1 \mathrm{cal} / \mathrm{mol} / \mathrm{deg})$ also indicated an apparent negative enthalpy value $(\Delta \mathrm{G}=-6.0)$ during the binding of NNM to the TMV CP monomers (Figure 4B), indicating that the CP-NNM complex is stable. 


\section{Molecular dynamics (MD) simulation}

To identify the NNM recognition sites in the TMV $\mathrm{CP}$, we performed molecular docking using the Gold method with 200 cycles. Six binding sites involving Ser14, Ser15, Ser49, Trp52, Arg71 and Tyr72 were found in the representative conformations (Supplementary Figure 2, conformations 1 to 6). After optimization, conformations 3 and 6 were considered as the optimum (Supplementary Figures $2 \mathrm{C}$ and $2 \mathrm{~F}$ ). In conformation 3, five strong hydrogen bonds involving Ser15 (one H bond with NNM), Ser49 (one), Arg71 (two) and Tyr72 (one) can be formed between the CP and NNM (Figure 5A and Supplementary Figures $3 \mathrm{~A}-\mathrm{C})$. However, in conformation 6 , three strong hydrogen bonds involving Ser15 (one), Ser49 (one) and Arg71 (one) were formed (Supplementary Figures 3D-F). Trajectory dynamics and a critical distance analysis revealed that both conformations 3 (Figures 5B-C and Supplementary Figures 4A-E) and 6 (Supplementary Figures $4 \mathrm{E}-\mathrm{H}$ ) are stable during $\mathrm{MD}$ simulations. There are more hydrogen bonds formed between the small molecule and the CP in conformation 3, with four stronger hydrogen bond interactions observed in the final state's structure. However, fewer hydrogen bonds were formed between the small molecule and $\mathrm{CP}$ in conformation 6 , with three hydrogen bond interactions observed in the final state's structure. As a result, in conformation 3, the electrostatic interaction between the CP and NNM was great, indicating that was optimum conformation potentially formed by NNM and the TMV CP monomer (Figures 5A-C). Using conformation 3 as an example, five hydrogen bonds involving Ser15, Ser49, Arg71 and Tyr72 were formed between the CP and NNM at the beginning of the MD simulations. The strengths and numbers of hydrogen bonds involving Ser15, Ser49, Arg71
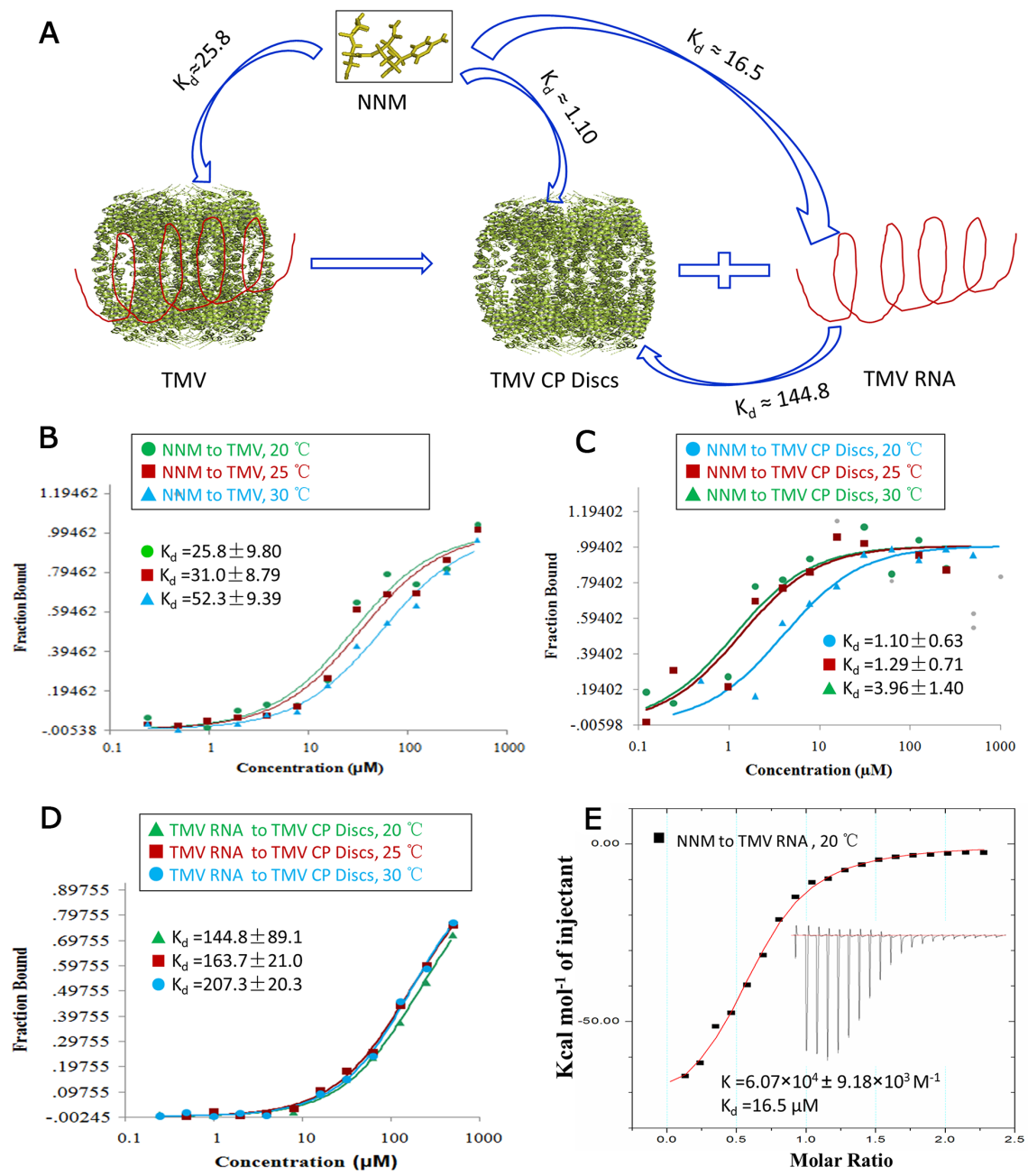

Figure 1: Interaction analysis of TMV-NNM, CP disc-NNM, CP disc-RNA, NNM-RNA. (A) schematic illustration of interactions of TMV-NNM, CP-NNM, CP-RNA; (B) MST results showed that the $\mathrm{Kd}$ of NNM-TMV was $25.8-52.3 \mu \mathrm{M}$ from 20 to $30^{\circ} \mathrm{C}$ (Supplementary Table 2); (C) MST results showed that the Kd of NNM-CP was 1.10-3.96 $\mu \mathrm{M}$ from 20 to $30^{\circ} \mathrm{C}$ (Supplementary Table 2); (D) MST results showed that the Kd of CP-RNA was $144.8-267.3 \mu \mathrm{M}$ from 20 to $30^{\circ} \mathrm{C}$ (Supplementary Table 2); (E) ITC results showed that six NNM combined one RNA with a $\mathrm{Kd}$ of $16.5 \mu \mathrm{M}$ at $20^{\circ} \mathrm{C}$ (Supplementary Table 2). 
and Tyr72 did not significantly change during the MD simulations (Figure 5D).

We also performed MD simulations of the interactions between two adjacent CP monomers. Only two hydrogen bonds, Ser15-Asn25 and Tyr2-Thr28 were found by molecular docking (Figure 5E). Additionally, the MD simulation analysis showed that the interactions among the CP monomers were stable in the initial structure with approximately $1 \AA$ fluctuations at the final state $(4,110 \mathrm{ps})$ of structural dynamics (Supplementary Figure 5). Taken together, these analyses revealed that the binding of NNM to the CP has a greater affinity than those seen in the interactions among CP monomers in the formation of dimers, oligomers or discs. Such a difference underlies the capability of NNM to induce the disassembly of CP discs.

\section{Mutational analysis of the protein-ligand interaction between NNM and CP}

To analyze the roles of the residues in the $\mathrm{CP}$ identified in the simulations as being critical for binding NNM, we constructed and expressed four CP mutants, S15G, S49G, R71G and Y72G. SEC and TEM revealed that approximately $50 \%$ of the mutated CPs assembled into discs (Figures 6A-B). When NNM was added at a 1:20 (CP discs:NNM) ratio, only approximately 35\% of mutated protein discs disassembled into protein monomers (Figures 6B-C). Furthermore, an analysis by MST revealed that the $\mathrm{Kd}$ of an NNM-mutant $\mathrm{CP}$ disc was approximate $43.5 \mu \mathrm{M}$ (Figure 7A), which was weaker than the NNM-CP disc (Figure 1C). The Kd of NNM-mutant $\mathrm{CP}$ monomer was approximate $211.8 \mu \mathrm{M}$ (Supplemental Figure 6A), which was weaker than the NNM-CP monomer (Figure 3B). The Kd of mutant CP monomermonomer was approximate $989.6 \mu \mathrm{M}$ (Supplementary Figure 6B), which was weaker than the $\mathrm{CP}$ monomermonomer (Figure 3C). Thus, the four residues interacted with NNM in a competitive manner.

\section{Evaluating NNMs ability to inhibit TMV replication in vivo}

To assess whether NNM can inhibit TMV CP replication in a systemic infection of the host Nicotiana tabacum cv. $K_{326}$ (N. tabacum cv. $K_{326}$ ), the leaf disc method along with western blot analysis, of TMV CP exposed to $0.5 \mathrm{mg} / \mathrm{mL}$ NNM for 24-96 h were carried out. The bands

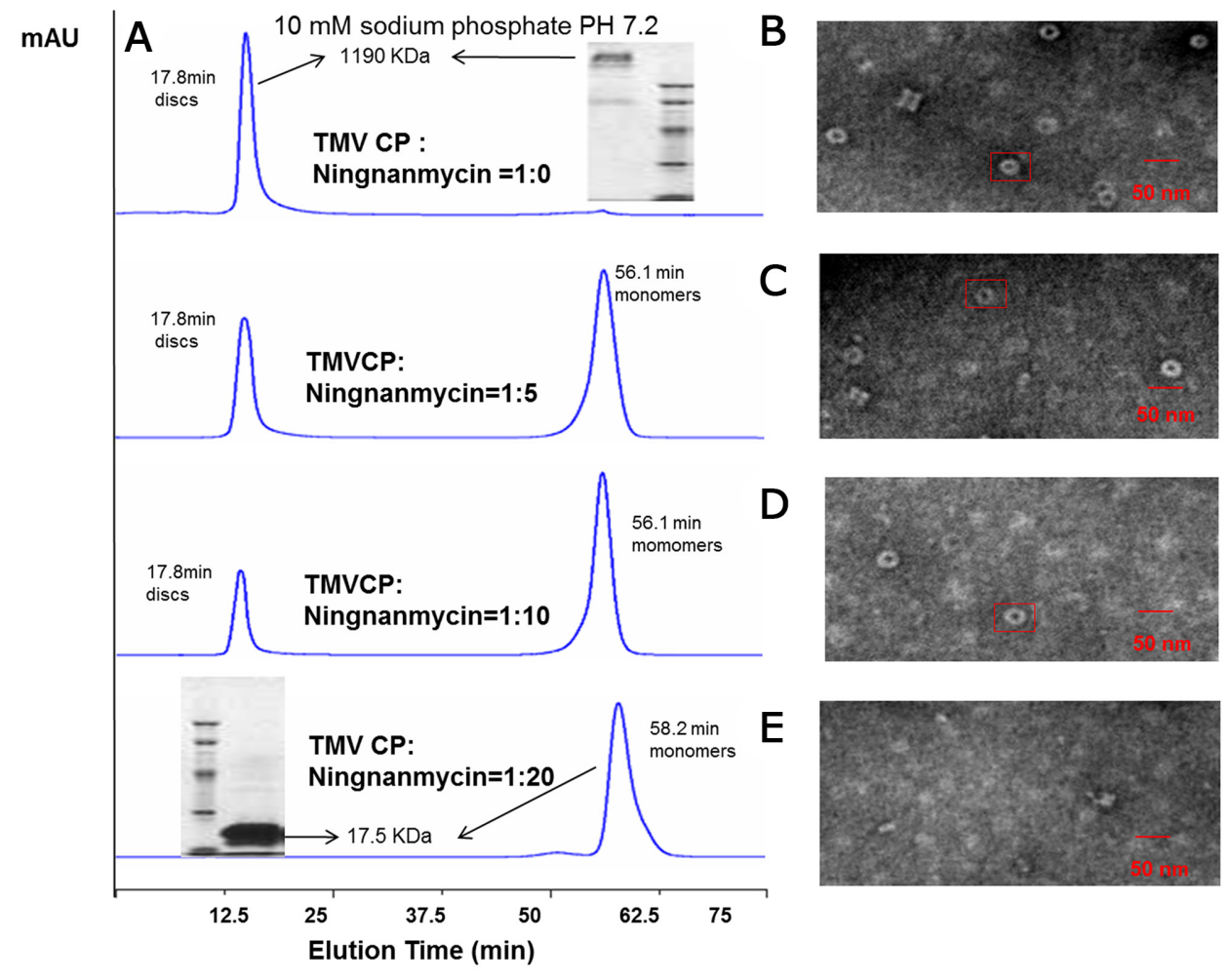

Figure 2: Interaction analysis of TMV CP discs-NNM. (A) The interactions of CP discs-NNM was analyzed using SEC. Note that the four-layer aggregate discs were eluted at $17.8 \mathrm{~min}$ with an approximate molecular weight of $1190 \mathrm{kDa}$, and CP monomers were eluted at 56.1-65 min with $17.5 \mathrm{kDa}$. Inserts are molecular weight estimated using native PAGE; (B-E) The four-layer aggregate discs in the corresponding samples visualized using TEM. Note that the four-layer aggregate discs were invisible when NNM was added to 20 times of the $\mathrm{CP}(\mathrm{E})$. 
of the CP were weak when sprayed with $0.5 \mathrm{mg} / \mathrm{mL}$ NNM for $24 \mathrm{~h}$ and the bands of the CP were not visible after $72 \mathrm{~h}$ (Figure 8A), which indicated that the newly assembled TMV virions in tobacco were inhibited by NNM Additionally, we collected the mutated protein discs and reconstituted a protein solution of $1.7 \mathrm{mg} / \mathrm{mL}$, which was incubated with 0.5 $\mathrm{mg} / \mathrm{mL}$ TMV RNA for $30 \mathrm{~min}$ to reconstitute viral particles (Figure 8B). In TMV inoculation assays, the infectivity of

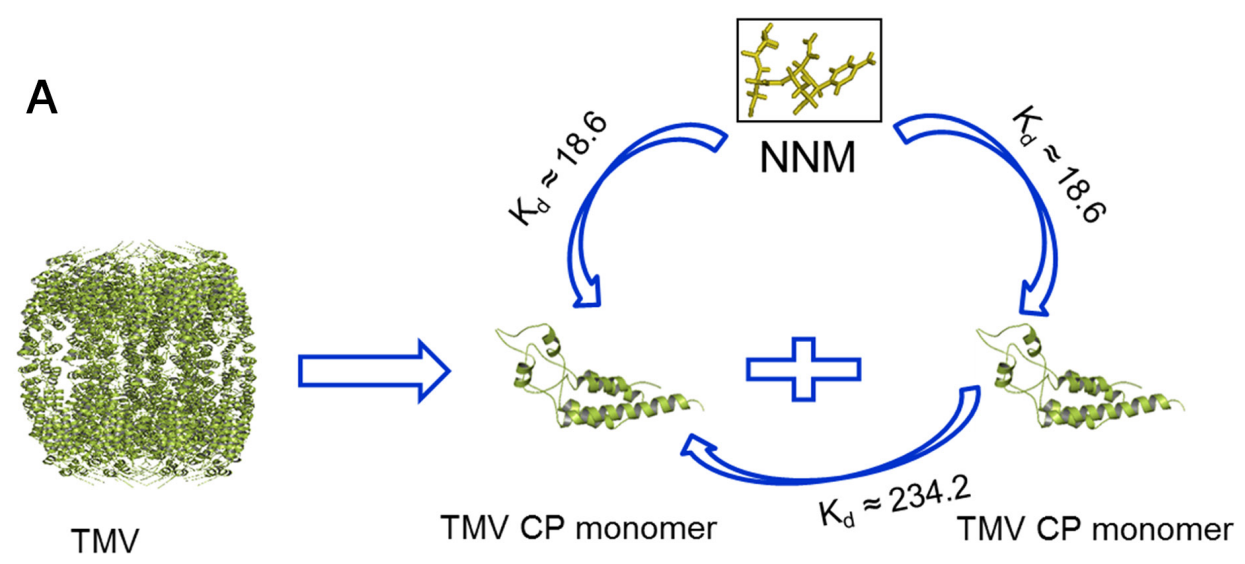

B

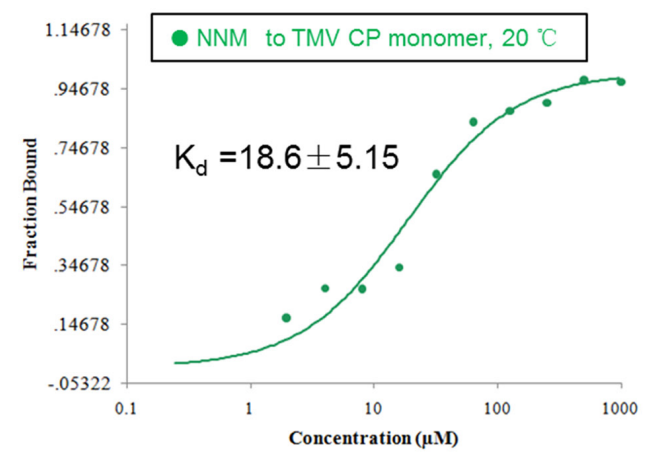

C

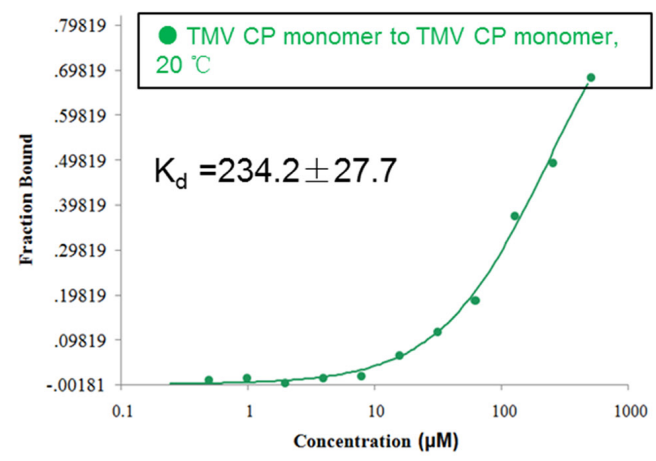

Figure 3: Interaction analysis of CP monomer-NNM, CP monomer-monomer. (A) schematic illustration of the interactions of CP monomer-NNM, CP monomer-monomer; MST results showed that the Kd of NNM-CP monomer was18. $6 \mu \mathrm{M}$ (B) and the Kd of $\mathrm{CP}$ monomer-monomer was $234.2 \mu \mathrm{M}(\mathbf{C})$ at $20^{\circ} \mathrm{C}$ (Supplementary Table 2).
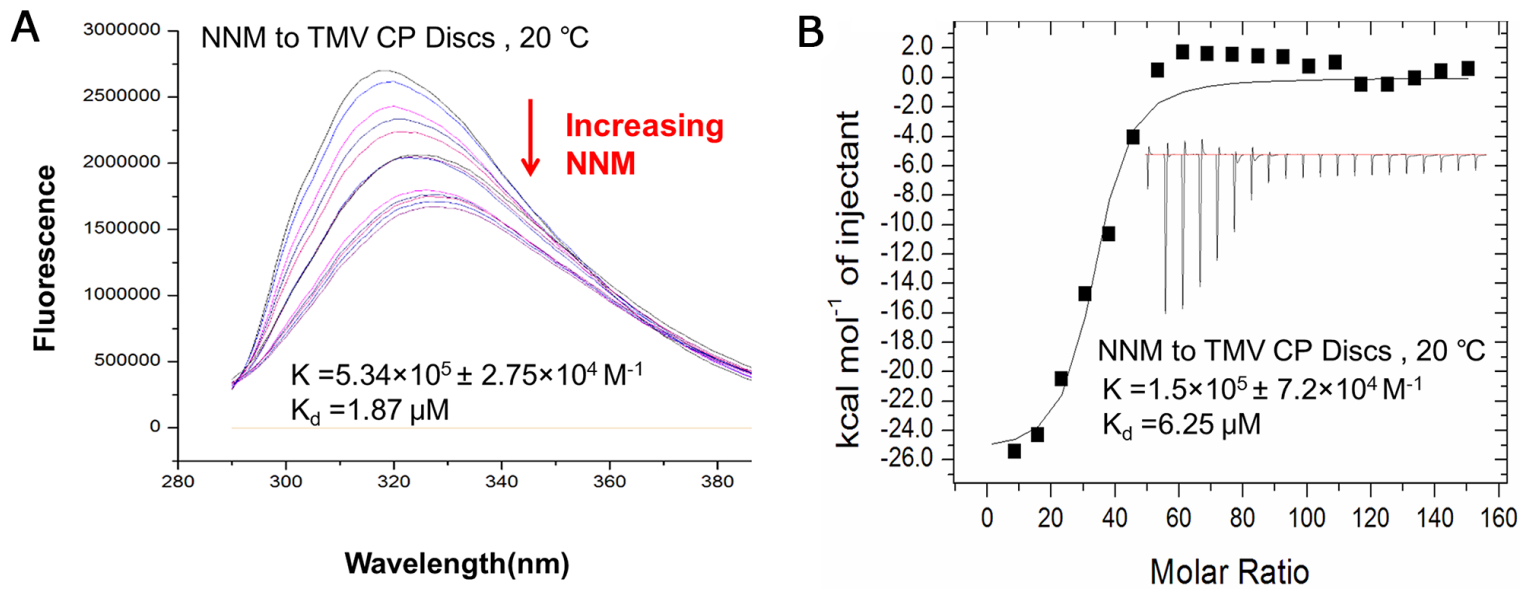

Figure 4: Interaction analysis of NNM-CP disc using fluorescence and ITC. (A) Fluorescence measurements showed that the Kd of NNM-CP disc was $1.87 \mu \mathrm{M}$ (Supplementary Table 2); (B) ITC results showed that one CP disc combined 39-41 NNM with a Kd of $6.25 \mu \mathrm{M}$ (Supplementary Table 2). 
the viruses derived from mutated $\mathrm{CP}$ significantly decreased (Figure 8C). Additionally, the mean lesions caused by the mutant viruses were about one quarter the size of those caused by the full-length reconstituted virus (Figure 8D). Thus, residues Ser15, Ser49, Arg71 and Tyr72, which were identified in computational simulations, indeed play key roles in the NNM-CP interactions.

\section{The use of CP discs as targets to screen anti- TMV compounds}

The effects of NNM suggest that the CP of TMV is a potential anti-viral drug target. Thus, the effects of several compounds on the properties of the $\mathrm{CP}$ were tested. In total, $0.5 \mathrm{mM}(8.7 \mathrm{mg} / \mathrm{mL})$ of fresh TMV CP discs were mixed

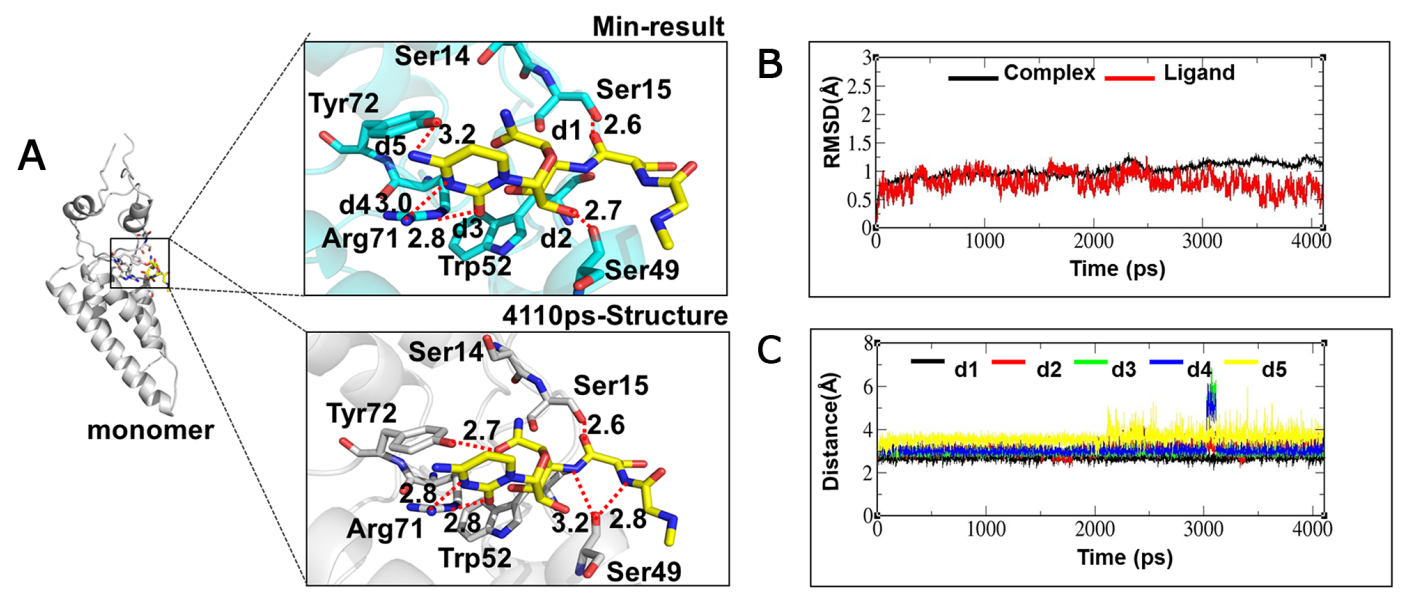

\begin{tabular}{ll}
$D$ & \multicolumn{2}{l}{ Parameter results of MD } \\
\cline { 2 - 2 } parameters & Values $(\mathrm{kcal} / \mathrm{mol})$ \\
\hline$\triangle H$ & -21.81 \\
$-\mathrm{T} \triangle \mathrm{S}$ & 9.97 \\
$\triangle \mathbf{G}$ & -11.84 \\
\hline
\end{tabular}

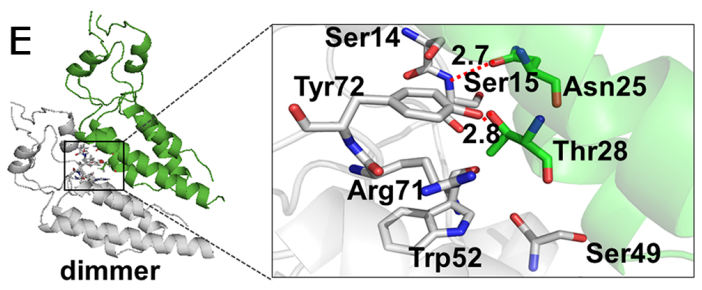

Figure 5: Interaction analysis of NNM-CP monomer and CP monomer-monomer using MD. (A) Conformational analysis of CP monomer-NNM; (B) Dynamics trajectory analysis of NNM-monomer; (C) Critical distance analysis of NNM-monomer; (D) Dynamic trajectory data of NNM-monomer at the last 1ns; (E) Conformational analysis of CP monomer-monomer.

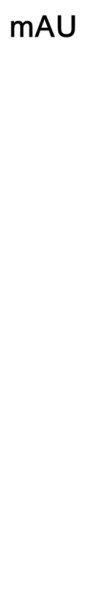

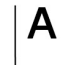
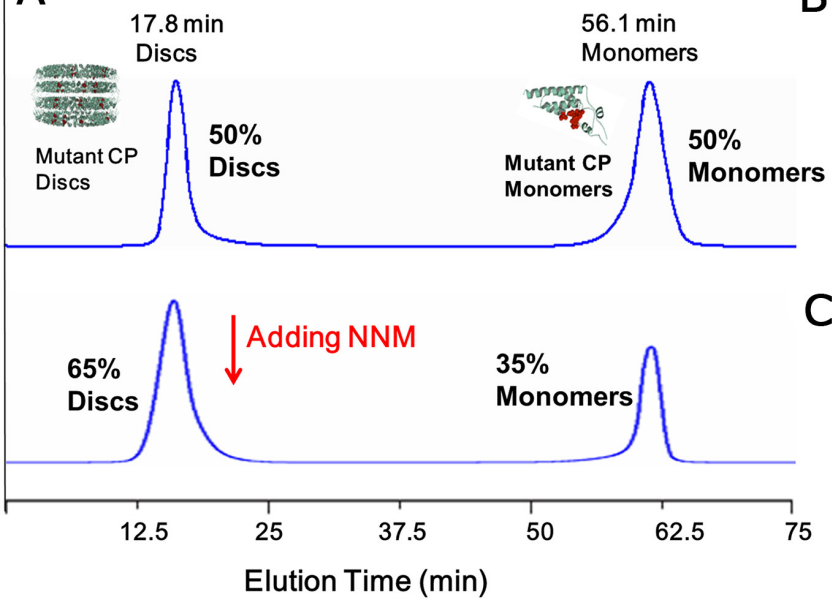

B

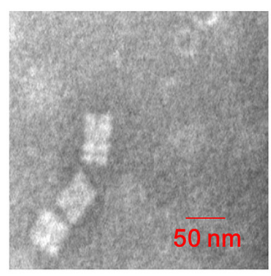

C

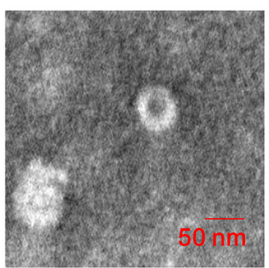

Figure 6: Analysis of the interactions of mutated CP-CP and mutated CP disc-NNM. (A) About 50\% mutated CP discs and $50 \%$ mutated CP monomers were visible using SEC; when adding the excessive NNM, about $65 \%$ mutated CP discs and $35 \%$ mutated CP monomers were visible in $10 \mathrm{mM}$ sodium phosphate buffer using SEC. The presence of the discs was evaluated using TEM, mutated CPs (B) and mutated CP-NNM (C). 
independently with $5 \mathrm{mM}$ NK0209 or cytosinpeptidemycin. Reactions with NNM were used as controls in all of the assays. The $\mathrm{Kd}$ values of treatments with compounds NK0209 or cytosinpeptidemycin bound to TMV CP discs and their mutants are listed in Supplementary Table 2. The affinities of the compounds to the mutant CP were weaker than the affinities of the compounds to the fulllength $\mathrm{CP}$, indicating that the mutation sites in the $\mathrm{CP}$ are the key residues (Figures 7B-7C). Based on compounds being capable of binding $\mathrm{CP}$ directly, $\mathrm{CP}$ can be regarded as anti-TMV compound target. Thus, we screened anti-
TMV compounds and found that compounds NK0209 and cytosinpeptidemycin were capable of binding CP directly. Furthermore, NK0209 and cytosinpeptidemycin exhibited significant anti-TMV activities in $500 \mu \mathrm{g} / \mathrm{mL}$ and had very good controlled effects (Supplementary Table 3) against TMV-associated disease in a vivo experiment. Our results support a model in which the disruption of the CP structure begins with the binding of NNM to CP within the fourlayer CP aggregate. This binding leads to the disassembly of the CP discs into monomers in complex with the small molecules. Traditionally, the prevention of infection, by

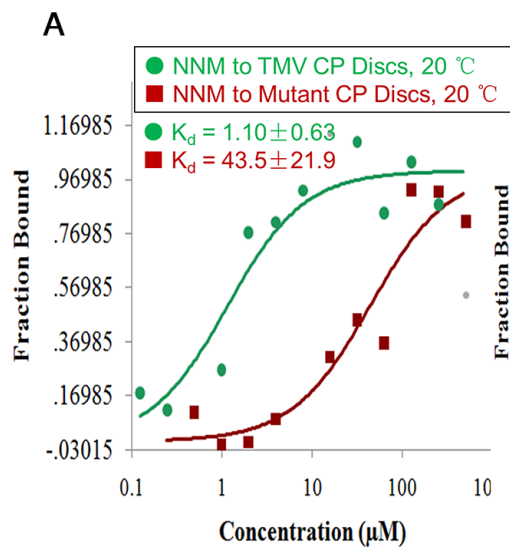

B

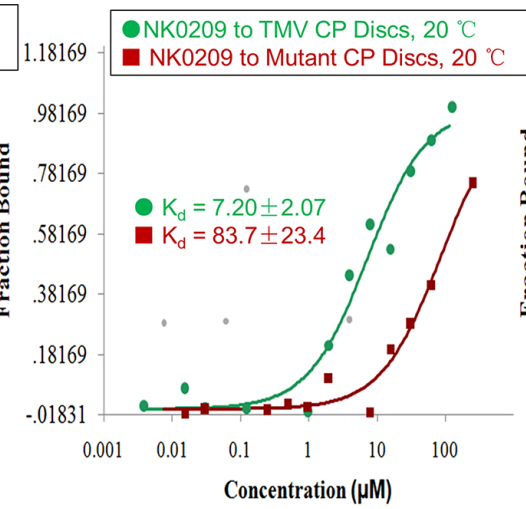

C

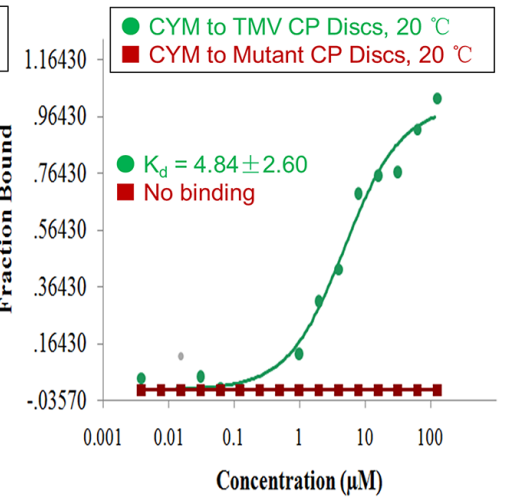

Figure 7: Binding analysis of NNM-CP, NK0209-CP and cytosinpeptidemycin-CP. (A) MST results showed that the Kd of NNM-CP monomer was $1.10 \mu \mathrm{M}$, the Kd of NNM-mutated CP disc was $43.5 \mu \mathrm{M}$ at $20^{\circ} \mathrm{C}$ (Supplementary Table 2); (B) MST results showed that the Kd of NK0209-CP monomer was $7.20 \mu \mathrm{M}$, the Kd of NK0209-mutated CP disc was $83.7 \mu \mathrm{M}$ at $20^{\circ} \mathrm{C}$ (Supplementary Table 2); (C) MST results showed that the Kd of cytosinpeptidemycin-CP monomer was $4.84 \mu \mathrm{M}$, there is no binding between cytosinpeptidemycin and the mutated CP disc, which is in good agreement with the binding results obtained using fluorescence and ITC (Supplementary Table 2).

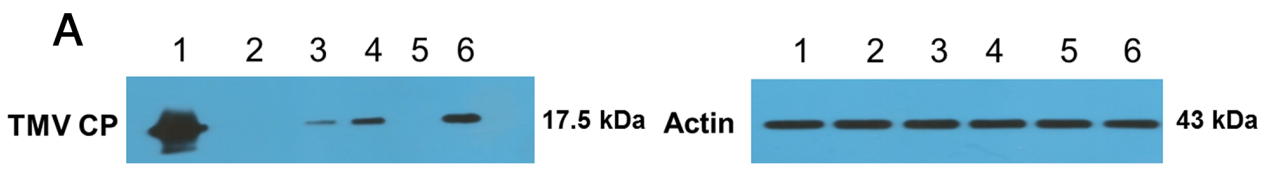

\begin{abstract}
Note: lane 1, inoculation with TMV for $96 \mathrm{~h}$; lane 2, inoculation with TMV for $24 \mathrm{~h}$, after that spraying 500 $\mu \mathrm{g} / \mathrm{mL}$ NNM for $72 \mathrm{~h}$; lane 3, inoculation with TMV for $24 \mathrm{~h}$, after that spraying $500 \mu \mathrm{g} / \mathrm{mL}$ NNM for $24 \mathrm{~h}$; lane4, inoculation with TMV for $24 \mathrm{~h}$; lane 5, inoculation with TMV for $24 \mathrm{~h}$, after that spraying $500 \mu \mathrm{g} / \mathrm{mL}$ NNM for $96 \mathrm{~h}$; lane 6, inoculation with TMV for $120 \mathrm{~h}$.
\end{abstract}

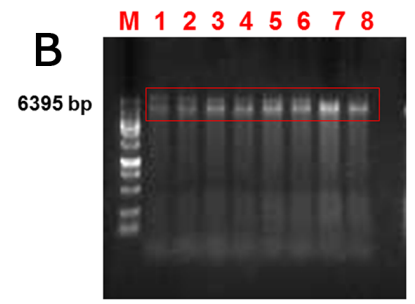

TMV CP RNA

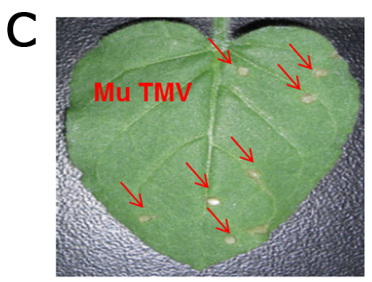

TMV CP mutant with RNA

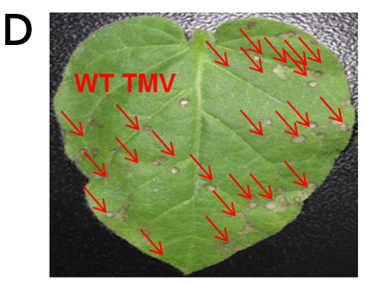

TMV CP with RNA

Figure 8: Western blot analysis of inhibition activities of NNM against TMV CP replication and verification of the virulence of TMV reconstituted particles from wt CP and mutated CP. (A) The bands of CP were weak when treated with $500 \mu \mathrm{g} / \mathrm{mL}$ NNM, the molecular weight of CP is $17.5 \mathrm{kDa}$, and the actin control was added with $43 \mathrm{kDa}$; (B) TMV RNA integrity (lanes 1-8) was examined by $1 \%$ agarose gel electrophoresis; (C) Leaves of $N$. glutinosa were inoculated with the reconstituted TMV derived from mutated CP. Local lesions caused by mutated TMV were labeled with red arrows, note the less severe symptoms; (D) The $N$. glutinosa was inoculated with the reconstituted wt TMV, the local lesions induced by the reconstituted wt TMV were labeled with red arrows. 
measures such as the use of virus-free seedlings, has been considered the only effective way to control plant viral diseases. The ability of NNM to induce the disassembly of $\mathrm{CP}$ discs suggests that this compound may effectively cure established TMV infections.

\section{DISCUSSION}

To explore the CP of TMV as a potential drug target, we took advantage of recombinant CP being similarly active to its native form by examining the effects of small molecules on the disassembly of CP discs. Our efforts led to the identification of NNM as a potent agent that induced the disassembly of TMV CP discs. To the best of our knowledge, this is the first example demonstrating that the targeting of a viral CP's physiochemical properties by small molecular agents is an effective strategy in controlling diseases caused by plant viruses.

The interactions between NNM and TMV CP monomers were mediated by at least five strong hydrogen bonds, which were significantly stronger than those that mediated the interactions among CP monomers. The interactions among individual subunits in protein complexes are normally dynamic, and the complexes can be seen as one end of the equilibrium. By binding to $\mathrm{CP}$ discs with a greater affinity, NNM could tilt the balance toward complexes formed between the CP and the molecule itself, leading to the disruption in the disc's structure.

Our results support a model in which the disruption of the CP structure begins with the binding of NNM to CP in the four-layer CP aggregate. Such binding leads to the disassembly of the $\mathrm{CP}$ discs into monomers complexed with the small molecules. Traditionally, the prevention of infection, by measures such as the use of virus-free seedlings, was considered the only effective means for controlling plant viral diseases [27]. The ability of NNM to induce the disassembly of CP discs suggests that this compound may effectively cure established TMV infections.

The notion that NNM functions by competing with residues involved in hydrogen bonds, which are responsible for the interactions among $\mathrm{CP}$ monomers, was further supported by the observation that mutations in residues (S15G, S49G, R71G, and Y72G) may impair the sensitivity of CP to NNM-induced disassembly. For example, residues Ser15 and Tyr72 are critical for the formation of hydrogen bonds among CP monomers. Yet, both residues are involved in the binding to NNM. Clearly, the competition for binding sites contributes to the effects of NNM. Further, the fact that viral particles containing the mutant CP are less virulent is in line with their roles in stabilizing the CP. Finally, our results also provide evidence indicating that $\mathrm{CP}$ plays an important role in the pathogenesis of TMV.

The interactions of the test compounds NK0209 and cytosinpeptidemycin with TMV CP mutated discs reduced the binding ability of CP mutants as assessed by MST, which was in good agreement with the binding results obtained by fluorescence spectrum and ITC. The value of using CP as a target for anti-viral agent development was further validated by the identification of several additional compounds that are capable of binding CP directly and reducing TMV virulence. In summary, our results demonstrate that TMV CP discs could be used as a new model target to screen for anti-TMV compounds. Because CP assembly is a critical step in the maturation of many viruses, including those of animals, our method could, in principle, be used to identify agents that act against viruses that pose threats to human health or agricultural production.

\section{MATERIALS AND METHODS}

\section{Materials}

NNM was kindly provided by Chen Jia-ren, Chengdu Institute of Biology, Chinese Academy of Sciences. NK0209 was synthesized by Wang Qing-min of the Research Institute of Elemento-Organic Chemistry. Cytosinpeptidemycin was bought from Fujian Quanzhou biopharmaceutical companies (Supplementary Table 4).

\section{Constructing recombinant TMV CP}

To prepare TMV CP discs, TMV was purified using the method described by Gooding and modified by Shire $[25,26]$. TMV RNA was extracted from the purified virus by treating with phenol and sodium dodecyl sulfate (SDS) $[27,28]$. TMV RNA was reverse transcribed using the previously described primers in $50 \mathrm{mmol} / \mathrm{L}$ Tris solution at $\mathrm{pH} 8.0$, containing $8.0 \mathrm{mmol} / \mathrm{L}$ magnesium chloride, 75 $\mathrm{mmol} / \mathrm{L}$ potassium chloride, $10 \mathrm{mmol} / \mathrm{L}$ DL-dithiothreitol, $1.0 \mathrm{mmol} / \mathrm{L}$ dNTPs, 0.5 unit/ $\mu \mathrm{L}$ AMV reverse transcriptase (TaKaRa, Shiga, Japan), and 1.0 unit/ $\mu \mathrm{L}$ RNase inhibitor (TaKaRa) for $1.5 \mathrm{~h}$ at $42{ }^{\circ} \mathrm{C}$ to generate the full-length viral cDNA sequence [6]. Following the generation of the full-length viral cDNA, the coding region of the TMV CP was amplified by PCR [6]. dsDNA of the full-length was purified and analyzed by $1 \%$ agarose gel electrophoresis. pET28a (Novagen, Madison, WI, USA) and TMV CP were digested using Nde I (NEB, Hertfordshire, England, 10 units $/ \mu \mathrm{L}$ )/Xho I (NEB, 10 units $/ \mu \mathrm{L}$ ) and cloned into similarly digested pET28a. Escherichia coli strain BL21 (DE3)-plysS (Novagen) was transformed with the aforementioned recombinant plasmid. Cultures for protein expression were grown in Luria-Bertani medium containing $30 \mu \mathrm{g} / \mathrm{mL}$ kanamycin at $37^{\circ} \mathrm{C}$ until the optical density at $600 \mathrm{~nm}$ reached 0.7 . After cooling the cultures to $16^{\circ} \mathrm{C}$, the expression was induced by adding isopropyl $\beta$-D-1thiogalactopyranoside to $0.5 \mathrm{mmol} / \mathrm{L}$, and induction was allowed to proceed for $16 \mathrm{~h}$. The cells were harvested by centrifugation and resuspended in $40 \mathrm{~mL}$ lysis buffer (100 $\mathrm{mmol} / \mathrm{L}$ sodium chloride and $50 \mathrm{mmol} / \mathrm{L}$ phosphate buffer [pH 8.0] and $10 \mathrm{mmol} / \mathrm{L} \beta$-mercaptoethanol). The cells were 
thawed, lysed using a supersonic device, and centrifuged at $13,400 \times \mathrm{g}$ for $30 \mathrm{~min}$ at $4^{\circ} \mathrm{C}$. After passing through a 0.22-mm syringe filter (Millipore, Schwalbach, Germany), the supernatant was loaded onto a $\mathrm{Ni}^{2+}$ Sepharose HighPerformance Column (GE Healthcare, Piscataway, NJ, USA), washed with five column volumes of $40 \mathrm{mmol} / \mathrm{L}$ imidazole and eluted with $400 \mathrm{mmol} / \mathrm{L}$ imidazole. The elute was concentrated using an Amicon Ultra centrifugal filter device (Millipore) with a $10 \mathrm{kDa}$ MW filter and then loaded onto a HiLoad 16/60 Superdex 200 pg column equilibrated with a dialysis solution $(10 \mathrm{mM}$ sodium phosphate buffer and $100 \mathrm{mM}$ sodium chloride solution [pH 7.2]). After thrombin digestion of $6 \times \mathrm{His}$ tags at $4^{\circ} \mathrm{C}$ overnight, TMV CP was further purified by SEC using a Superdex 200 10/300 GL column (GE Healthcare) and a buffer containing $10 \mathrm{mM}$ sodium phosphate and $100 \mathrm{mM}$ sodium chloride solution ( $\mathrm{pH}$ 7.2). Proteins were then concentrated to $8.7 \mathrm{mg} / \mathrm{mL}$ for biochemistry experiments using amicon ultra centrifugal filter units (Millipore) with a $10 \mathrm{kDa} \mathrm{MW}$ cutoff. The target proteins were briefly stored at $4^{\circ} \mathrm{C}$. TMV (common strain) was isolated from infected tobacco leaves (grown in the greenhouse at Guizhou University) and purified [25, 26]. The CP was separated and purified using the modified acetic acid degradation method and dialyzed against the appropriate high-salt buffer at room temperature to obtain the four-layer aggregate [6].

\section{Functional determination of recombinant TMV CP}

The recombinant proteins with $6 \times$ His tags were purified using $\mathrm{Ni}^{2+}$ beads and the tags were cleaved using thrombin. TMV CP was examined for the formation of oligomers with SEC methods. Discs were formed by incubating the oligomers in $10 \mathrm{mM}$ sodium phosphate buffer containing $100 \mathrm{mM}$ sodium chloride $(\mathrm{pH} \mathrm{7.2)}$ at $22^{\circ} \mathrm{C}$ for more than $12 \mathrm{~h}[6]$. TMV CP discs were detected by native PAGE after TMV CP oligomers were incubated at $22^{\circ} \mathrm{C}$ for $24 \mathrm{~h}$, and the formation of four-layer aggregate discs was confirmed by SEC. The refolding and further self-assembly of TMV CP were performed with a protein concentration of $8.7 \mathrm{mg} / \mathrm{mL}$ incubated at $22^{\circ} \mathrm{C}$ for $24 \mathrm{~h}$, and the four-layer aggregate discs were observed by TEM. To reconstitute TMV particles, the same concentration of $\mathrm{CP}$ was incubated with $2 \mathrm{mg} / \mathrm{mL}$ TMV RNA at $22^{\circ} \mathrm{C}$ for $24 \mathrm{~h}$. The freshly purified TMV CP oligomers that selfassembled into TMV CP discs could be reconstructed into newly infectious viruses [6].

\section{Interactions between NNM and TMV CP}

NNM and TMV CP binding was initiated by adding $5 \mathrm{mM}$ anti-TMV compounds to $0.5 \mathrm{mM}(8.7 \mathrm{mg} / \mathrm{mL}) \mathrm{TMV}$ $\mathrm{CP}$ discs and incubating for $1 \mathrm{~h}$. Then, $0-10 \mathrm{mM} \mathrm{NNM}$ was added to the reactions for $1 \mathrm{~h}$. The oligomer status of TMV was then analyzed by SEC [6]. SEC was performed at room temperature using a calibrated Superdex 200 10/300 GL column (GE Healthcare) attached to an AKTA Purifier Fast Protein Liquid Chromatography system (GE Healthcare). The column was equilibrated with a buffer containing 10 $\mathrm{mM}$ sodium phosphate and $100 \mathrm{mM}$ sodium chloride solution ( $\mathrm{pH}$ 7.2). The molecular mass standards (Bio-Rad Hercules, CA, USA) used included thyroglobulin (669 $\mathrm{kDa})$, ferritin (440 kDa), Bovine Serum Albumin (67 kDa), $\beta$-lactoglobulin (35 kDa), ribonuclease A (13.7 kDa), cytochrome $(13.6 \mathrm{kDa})$, aprotinin $(6.51 \mathrm{kDa})$ and vitamin B12 (1.36 kDa). The protein was monitored by measuring the absorbance at a wavelength of $280 \mathrm{~nm}$. For TEM [6, 22, 23], self-assembled TMV CP discs were incubated as described previously. Briefly, $20 \mu \mathrm{L}$ of the mixed solution was deposited onto a 300-mesh formvar-carbon-coated copper grid for $2 \mathrm{~min}$, followed by rinsing with $\mathrm{ddH}_{2} \mathrm{O}$. The grid was stained with $20 \mu \mathrm{L}$ of $2 \%$ aqueous solution of tungstophosphoric acid for $90 \mathrm{~s}$ as a negative stain. Images were obtained at the Electron Microscope Lab of Zunyi Medical University using a Hitachi H-7650 transmission electron microscope (Tokyo, Japan) with $80 \mathrm{kV}$ accelerating voltage. The $17 \%$ native PAGE [29-31] was performed on ice with TMV CP samples equilibrated overnight in a buffer containing $10 \mathrm{mM}$ sodium phosphate and $100 \mathrm{mM}$ sodium chloride ( $\mathrm{pH} 7.2$ ). Then, $20 \mu \mathrm{L}$ of the samples was mixed with $20 \mu \mathrm{L}$ of $2 \times$ loading buffer $(12.5 \% 0.5 \mathrm{M}$ Tris- $\mathrm{HCl}$ $(\mathrm{v} / \mathrm{v})(\mathrm{pH}=8.7), 0.5 \%$ bromophenol blue $(\mathrm{w} / \mathrm{v})$ and $30 \%$ glycerin (v/v). Subsequently, $8 \mu \mathrm{L}$ of the samples was loaded onto $17 \%$ gels. Electrophoresis was performed using a $1 \times$ native PAGE buffer (Tris-Gly, $\mathrm{pH} 8.8$ ) at $0{ }^{\circ} \mathrm{C}$ for $1 \mathrm{~h}$. After electrophoresis, gels were stained with Coomassie Brilliant blue to identify proteins, and then destained with methanol and glacial acetic acid. The fluorescence spectra [32] were recorded with a fluorescence spectrophotometer (Varian Cary Eclipse, Palo Alto, CA, USA) at $20^{\circ} \mathrm{C}$. The emission spectra of TMV CP discs were obtained in buffer $(1.5 \mathrm{~mL})$ with a quartz cuvette having a $1-\mathrm{cm}$ path length. Fluorescence intensities were measured with an excitation wavelength of $278 \mathrm{~nm}$ and an emission wavelength of 325 $\mathrm{nm}$. The concentrations of TMV CP discs were defined at $50 \mathrm{nM}$. NNM was continuously added into the cuvette until the fluorescence signal no longer changed. All measurements were taken in phosphate buffer $(10 \mathrm{mM}$ sodium phosphate, $100 \mathrm{mM}$ sodium chloride [pH 7.2]), and fluorescence titration curves were corrected for the background intensity of the buffer. The apparent dissociation constants were analyzed by the nonlinear leastsquares curve-fitting method using Origin 7.0 software. The ITC binding experiments [33] were performed using an ITC 200 Micro Calorimeter (GE Healthcare) at $20^{\circ} \mathrm{C}$. All recombinant $\mathrm{CP}$ proteins and mutants were formed in 10 $\mathrm{mM}$ sodium phosphate buffer and $100 \mathrm{mM}$ sodium chloride solution $\left(\mathrm{pH} \mathrm{7.2)}\right.$ at $20^{\circ} \mathrm{C}$ for more than $12 \mathrm{~h}$, and then recombinant $\mathrm{CP}$ four-layer aggregate discs and mutant discs were collected. The buffer contained $10 \mathrm{mM}$ sodium phosphate and $100 \mathrm{mM}$ sodium chloride $(\mathrm{pH}$ 7.2). The 
compounds $(0-10 \mathrm{mM})$ were titrated into TMV CP discs and mutants $(0.5 \mathrm{mM})$ in a $200 \mu \mathrm{L}$ sample cell using a $40-\mu \mathrm{L}$ microsyringe as follows: $0.4 \mu \mathrm{L}$ for the first injection and $2 \mu \mathrm{L}$ for the next 19 injections at intervals of $150 \mathrm{~s}$. The integrated heat data were analyzed using the one-set-of-sites model in MicroCal Origin 7.0 according to the manufacturer's instructions. The first data point was not used in analysis. The binding parameters reaction enthalpy change in $\mathrm{cal} \cdot \mathrm{mol}^{-1}(\Delta \mathrm{H})$, binding constant in $\mathrm{mol}^{-1}(\mathrm{~K})$ and the number of molecules per TMV CP proteins (n) were floating during the fit. The binding free energy, $\Delta \mathrm{G}$, and reaction entropy, $\Delta \mathrm{S}$, were calculated using the equations, $\Delta \mathrm{G}=-\mathrm{RT} \operatorname{lnK}\left(\mathrm{R}=1.9872 \mathrm{cal} \cdot \mathrm{mol}^{-1} \cdot \mathrm{K}^{-1}, \mathrm{~T}=298 \mathrm{~K}\right)$ and $\Delta \mathrm{G}=\Delta \mathrm{H}-\mathrm{T} \Delta \mathrm{S}$. The $\mathrm{Kd}$ was calculated as $1 / \mathrm{K}$. Then, the binding was calculated for MST $[34,35]$ Monolith NT. 115 (Nano Temper Technologies, Munchen, Germany). A range of ligands from $0 \mu \mathrm{M}$ to $5 \mu \mathrm{M}$ were incubated with $0.5 \mu \mathrm{M}$ of purified recombinant proteins for 5 min with a NT-647 dye (Nano Temper Technologies). These were used in the thermophoresis experiment at a final concentration of $\sim 20$ nM. A 16 point dilution series was made for selected compounds in dimethyl sulfoxide. Each compound's dilution series was subsequently transferred to protein solutions in $10 \mathrm{mM}$ Tris/ $\mathrm{HCl}$ and $100 \mathrm{mM}$ sodium chloride, $\mathrm{pH} 7.4$, containing $0.05 \%$ Tween-20. After a $15 \mathrm{~min}$ incubation of the labeled $\mathrm{CP}$ with each dilution point (1:1 mix) at room temperature, samples were placed into standard capillaries (NanoTemper Technologies). Measurements were taken on a Monolith NT.115 MST (NanoTemper Technologies) under the setting of 20\% LED and 40\% IR laser. The laser's on time was set at $30 \mathrm{~s}$, and the laser's off time was set at $5 \mathrm{~s}$. The $\mathrm{Kd}$ values were calculated from the duplicate reads of three separate experiments using the mass action equation in the Nano Temper software. For western blot [36], an electrotransfer system (Bio-Rad) was used. Growing leaves of $N$. tabacum $c v . \mathrm{K}_{326}$ were mechanically inoculated with equal volumes of TMV $(0.5 \mathrm{mg} / \mathrm{mL})$. After $72 \mathrm{~h}, 1-\mathrm{cm}$ diameter leaf discs were removed. The leaf discs were floated on solutions of NNM and on buffer (10 mM sodium phosphate and 100 $\mathrm{mM}$ sodium chloride solution, $\mathrm{pH}$ 7.2) as a negative control. Discs of healthy leaves were floated on buffer as a mock. All of the leaf discs were kept in a culture chamber at $28^{\circ} \mathrm{C}$ for $48 \mathrm{~h}$, and then, the TMV concentration in the leaf disc was determined. Leaf discs were ground in $5 \times$ protein loading buffer $(10 \% \mathrm{SDS}, 5 \% \beta$-ME, $50 \%$ glycerin, $0.5 \%$ bromophenol blue, and $250 \mathrm{mM}$ Tris- $\mathrm{HCl}, \mathrm{pH} 6.8$ ), and then, $5 \mu \mathrm{L}$ of sample were loaded on a polyacrylamide gel (5\% stacking gel and $12 \%$ separating gel). After SDSPAGE, TMV protein bands were transferred at $90 \mathrm{~mA}$ for 1 $\mathrm{h}$ onto a polyvinylidene fluoride membrane $(0.46 \mu \mathrm{m}$, washed with methanol to activate) using an electrotransfer system (Bio-Rad). The membrane was washed in TBST (20 $\mathrm{mM}$ Tris- $\mathrm{HCl}$, pH 8.0; $150 \mathrm{mM} \mathrm{NaCl}$; and $0.05 \%$ Tween-20) and blocked with 5\% nonfat milk powder in TBST for $1 \mathrm{~h}$ at $37^{\circ} \mathrm{C}$. The membrane was washed three times, each time for $3 \mathrm{~min}$ with TBST, and reacted with a mixture of 1:30,000 alkaline phosphadase-conjugated antirabbit IgG (Sigma, Deisenhofen, Germany) and 1:200 polyclonal antibody of TMV for $2 \mathrm{~h}$ at $37^{\circ} \mathrm{C}$. After it was washed three times, each time for $3 \mathrm{~min}$ with TBST, the membrane was incubated in substrate buffer (12.1 g Tris$\mathrm{HCl}, \mathrm{pH}$ 9.5; $5.84 \mathrm{~g} \mathrm{NaCl} ; 10.2 \mathrm{~g} \mathrm{MgCl}_{2}$; and $800 \mathrm{~mL} \mathrm{H}_{2} \mathrm{O}$ ) with $330 \mu \mathrm{L} / \mathrm{mL}$ nitrotetrazolium blue chloride and $165 \mu \mathrm{L} /$ $\mathrm{mL}$ 5-bromo-4-chloro-3-indolyl phosphate for 3-5 min in the dark until the bands of the CP were clear. For the MD simulation, the X-ray crystal structure of TMV CP was downloaded from (Protein Data Bank) PDB (PDB ID: $4 \mathrm{GQH})$. The initial structure was revised by adding lost residues and hydrogen atoms and checking bonds and bumps. Subsequently, the energy was minimized for 2,000 steps of the steepest descent calculations and 2,000 steps of conjugated gradient calculations by using Sybyl 7.0 (Tripos Inc., St. Louis, MO, USA) and Gaussian03 program at the $\mathrm{HF} / 6-31+\mathrm{G}^{*}$ level [37]. The optimized geometries were used to construct the entire structures. The final structures of different conformations were optimized by fixing the macrocycle with a conjugated gradient in Sybyl 7.0. The different conformations were used as the starting structures for docking studies. Docking calculations were performed on these conformations with AutoDock4.0. The protein and ligand structures were prepared with Autodock Tools [38]. The atomic Gasteiger-Huckel charges were assigned to the ligand and receptor. Most of the parameters for the docking calculation were set to the default values recommended by the software. Each docked structure was scored by the builtin scoring function and was clustered by $0.8 \AA$ of (rootmean-square deviation) RMSD criteria. For each binding model, the molecular mechanics/Poisson-Boltzmann surface area was calculated. Before this calculation, the complex structure was further refined initially with the steepest descent algorithm, followed by the conjugated gradient algorithm using the Amber9 package [39]. During the energy minimization process, the receptor was first fixed, and only the ligand remained free. Then, the ligand and residue side chains remained free. Finally, all atoms of the system were liberated and refined to a convergence of $0.01 \mathrm{kcal} /(\mathrm{mol} \cdot \AA)$.

Based on the docking results, two binding models were selected for MD simulation. Prior to the simulation, the electrostatic potential and partial atomic charges were determined by performing an electrostatic potential fitting according to the Merz-Singh-Kollman scheme with the Gaussian-optimized geometries [40, 41]. The rescaled electrostatic potential charges of the ligand were produced using the standard protocol implemented in the antechamber module of the Amber9 program [38, 42, 43]. The system was solvated in an octahedral box of TIP3P water, in which crystallographic water molecules were maintained. The edge of the box was at least $10 \AA$ from the solute. Appropriate sodium counterions were added to the system to preserve neutrality. The solvated system 
belonged to the solute. Before the MD simulation, some energy minimization steps were applied to the system. First, the solute was kept fixed with a constraint of 500 kcal $\mathrm{mol}^{-1} \AA^{-2}$. Water and counterions were minimized. The backbone atoms of the protein were then fixed with the ligand, side chains, and other atoms that are free to move. Finally, the entire system was fully minimized without any constraint. In each step, energy minimization was first performed using the steepest descent algorithm for 2,000 steps, and subsequently, the conjugated gradient algorithm was used for another 3,000 steps. The MD simulation was performed under periodic boundary conditions using the sander module of the Amber9 program. First, the system was fixed to heat only the water and counterions for 10 ps to make sure the solute was fully solvated. Then, the entire system was gradually heated from $10 \mathrm{~K}$ to $300 \mathrm{~K}$ using the weak-coupling method and equilibrated for 100 ps with the protein backbone fixed [44]. Lastly, the system was switched to a constant pressure equilibration (2 ns). During the MD simulation, the particle mesh Ewald algorithm was used to handle long-range electrostatic interactions with a cutoff distance of $10 \AA[45,46]$, which was also used for the van der Waals energy terms. All of the angles and bonds involving hydrogen atoms were constrained using the SHAKE algorithm [47]. The time step used for the MD simulations was $2.0 \mathrm{fs}$, and the coordinates were collected every 1 ps.

\section{Verifying the interaction between NNM and mutated TMV CP}

To verify the results of the MD simulation, four mutations [14], S15G, S49G, R71G, and Y72G, were introduced into the $\mathrm{CP}$, and the mutant proteins were used to measure the interactions between NNM and TMV CP as described previously (see interactions between NNM and TMV CP). Then, $1 \mathrm{~mL}$ of purified self-assembled mutant discs $(8.7 \mathrm{mg} / \mathrm{mL})$ were incubated in $10 \mathrm{mM}$ sodium phosphate and $100 \mathrm{mM}$ sodium chloride solution, $\mathrm{pH} 7.2$, and mixed with $0.2 \mathrm{~mL}$ purified TMV RNA $(2 \mathrm{mg} / \mathrm{mL})$. The mixture was incubated at $20^{\circ} \mathrm{C}$ for $24 \mathrm{~h}$. Suspensions were centrifuged at $2,700 \times \mathrm{g}$ for $1 \mathrm{~min}$, and reconstituted viruses were obtained [6].

Leaves of Nicotiana glutinosa (N. glutinosa) were mechanically inoculated with the reconstructed full-length virus or the reconstructed mutated virus (see the TEM methods). The local lesion numbers were recorded 3-4 days after inoculation.

\section{Abbreviations}

TMV, tobacco mosaic virus; CP, coat protein; NNM, ningnanmycin; MST, microscale thermophoresis; $\mathrm{Kd}$, dissociation constant; ITC, isothermal titration calorimetry; SEC, size-exclusion chromatography; TEM, transmission electron microscopy; wt, wild type; $N$. tabacum cv. $K_{326}$, Nicotiana tabacum cv. $K_{326}$; PDB, protein data bank; RMSD, root-mean-square deviation; RESP, rescaled electrostatic potential; $N$. glutinosa, Nicotiana glutinosa.

\section{Author contributions}

Prof. B. A. Song conceived and designed the experiments. Dr. X. Y. Li performed the experiments. Dr. G. F. Hao performed the molecular dynamics simulation. Dr. X. Y. Li, Y. Ding, L. Yu analyzed the data. Profs. Z. Chen, D. Y. Hu and Q. M. Wang contributed reagents/ materials/analysis tools. Profs. B. A. Song and Dr. X. Y. Li wrote and revised the manuscript. All authors have read and approved the final manuscript.

\section{CONFLICTS OF INTEREST}

The authors declare no conflicts of interest.

\section{FUNDING}

This work was supported by the National Natural Science Foundation of China (Grant Nos. 21132003, 31460460 and 21502032) and Subsidy Project for Outstanding Key Laboratory of Guizhou Province in China (20154004) and the Provincial University Cooperation Plan of Guizhou Province in China (No. 20147001) and Collaborative Innovation Center for Natural Products and Biological Drugs of Yunnan for supporting the project.

\section{REFERENCES}

1. Gao S, Zhang R, Yu Z, Xi Z. Antofine analogues can inhibit tobacco mosaic virus assembly through small-moleculeRNA interactions. Chembiochem. 2012; 13: 1622-1627.

2. Chen Z, Zeng MJ, Song BA, Hou C, Hu DY, Li XY, Wang ZC, Fan HT, Bi L, Liu JJ, Yu DD, Jin LH, Yang S. Dufulin activates HrBP1 to produce antiviral responses in tobacco. PLos One. 2012; 7: e37944. https://doi.org/10.1371/journal. pone. 0037944.

3. Ouyang G, Chen Z, Cai XJ, Song BA, Bhadury PS, Yang $\mathrm{S}$, Jin LH, Xue W, Hu DY, Zeng S. Synthesis and antiviral activity of novel pyrazole derivatives containing oxime esters group. Bioorg Med Chem. 2008; 16: 9699-9707.

4. Ramirez I, Araya S, Piovano M, Carvajal M, CuadrosInostroza A, Espinoza L, Garbarino JA, Pena-Cortes H. Lichen depsides and depsidones reduce symptoms of diseases caused by tobacco mosaic virus (TMV) in tobacco leaves. Nat Prod Commun. 2012; 7: 603-606.

5. Han Y, Ding Y, Xie DD, Hu DY, Li P, Li XY, Xue W, Jin LH, Song BA. Design, synthesis, and antiviral activity of novel rutin derivatives containing 1, 4-pentadien-3-one moiety. Eur J Med Chem. 2015; 92: 732-737. 
6. Li XY, Song BA, Chen X, Wang ZC, Zeng MJ, Yu DD, $\mathrm{Hu} \mathrm{DY}$, Chen Z, Jin LH, Yang S, Yang CG, Chen BE. Crystal structure of a four-layer aggregate of engineered TMV CP implies the importance of terminal residues for oligomer assembly. PLos One. 2013; 8: e77717. https://doi. org/10.1371/journal.pone.0077717.

7. Saito T, Yamanaka K, Okada Y. Long-distance movement and viral assembly of tobacco mosaic virus mutants. Virology. 1990; 176: 329-336.

8. Klug A. The tobacco mosaic virus particle: structure and assembly. Philos T Roy Soc B. 1999; 354: 531-535.

9. Sachse C, Chen JZ, Coureux PD, Stroupe ME, Fandrich M, Grigorieff N. High-resolution electron microscopy of helical specimens: a fresh look at tobacco mosaic virus. J Mol Biol. 2007; 371: 812-835.

10. Clare DK, Orlova EV. $4.6 \AA$ Cryo-EM reconstruction of tobacco mosaic virus from images recorded at $300 \mathrm{keV}$ on a 4k $\times$ 4k CCD camera. J Struct Biol. 2010; 171: 303-308.

11. Stubbs G, Warren S, Holmes K. Structure of RNA and RNA binding site in tobacco mosaic virus from $4-\AA$ map calculated from X-ray fibre diagrams. Nature. 1977; 267: 216-221.

12. Namba K, Stubbs G. Structure of tobacco mosaic virus at 3.6 Å resolution: implications for assembly. Science. 1986; 231: 1401-1406.

13. Lu B, Stubbs G, Culver JN. Carboxylate interactions involved in the disassembly of tobacco mosaic tobamovirus. Virology. 1996; 225: 11-20.

14. Culver JN, Dawson WO, Plonk K, Stubbs G. Site-specific mutagenesis confirms the involvement of carboxylate groups in the disassembly of tobacco. Virology. 1995; 206: 724-730.

15. Kegel WK, van der Schoot P. Physical regulation of the self-assembly of tobacco mosaic virus coat protein. Biophys J. 2006; 91: 1501-1512.

16. Bhyravbhatla B, Watowich SJ, Caspar DL. Refined atomic model of the four-layer aggregate of the tobacco mosaic virus coat protein at $2.4 \AA$ resolution. Biophys J. 1998; 74: 604-615.

17. Culver JN. Tobacco mosaic virus assembly and disassembly: determinants in pathogenicity and resistance. Annu Rev Phytopathol. 2002; 40: 287-308.

18. Bendahmane M. Characterization of mutant tobacco mosaic virus coat protein that interferes with virus cell-to-cell movement. Proc Nati Acad Sci U S A. 2002; 99: 3645-3650.

19. Asurmendi S, Berg RH, Koo JC, Beachy RN. Coat protein regulates formation of replication complexes during tobacco mosaic virus infection. Proc Nati Acad Sci U S A. 2004; 101: 1415-1420.

20. Asurmendi S. Aggregation of TMV CP plays a role in CP functions and in coat-protein-mediated resistance. Virology. 2007; 366: 98-106.

21. Abel PP. Delay of disease development in transgenic plants that express the tobacco mosaic virus coat protein gene. Science. 1986; 232: 738-743.
22. Bruckman MA. Role of hexahistidine in directed nanoassemblies of tobacco mosaic virus coat protein. ACS nano. 2011; 5: 1606-1616.

23. Dedeo MT, Duderstadt KE, Berger JM, Francis MB. Nanoscale protein assemblies from a circular permutant of the tobacco mosaic virus. Nano Lett. 2010; 10: 181-186.

24. Han Y. Induction of systemic resistance against tobacco mosaic virus by Ningnanmycin in tobacco. Pestic Biochem Phys. 2014; 111: 14-18.

25. Huey R, Morris GM, Olson AJ, Goodsell DS. A semiempirical free energy force field with charge-based desolvation. J Comput Chem. 2007; 28: 1145-1152.

26. Mu LX, Chen JG, Wu YH, Zhao XX. Structure determination and antifungal mechanism of cytosinpeptidemycin. Acta Phytopathol Sin. 2013; 43: 376-377.

27. Wang T, Yin S, Hu J. Dissipation and residue determination of ningnanmycin in cucumber and soil by high performance liquid chromatography with ultraviolet detector. B Environ Cont Tox. 2013; 90: 256-259.

28. Gooding GV, Hebert TT. A simple technique for purification of tobacco mosaic virus in large quantities. Phytopathology. 1967; 57: 1285.

29. Shire SJ, Steckert JJ, Adams ML, Schuster TM. Kinetics and mechanism of tobacco mosaic virus assembly: direct measurement of relative rates of incorporation of $4 \mathrm{~S}$ and 20 S protein. Proc Nati Acad Sci U S A. 1979; 76: 2745-2749.

30. Fraenkel-Conrat H, Singer B, Tsugita A. Purification of viral RNA by means of bentonite. Virology. 1961;14: 54-58.

31. Wilcockson J, Hull R. The rapid isolation of plant virus RNAs using sodium perchlorate. J Gen Virol. 1974; 23: 107-111.

32. Castellanos-Serra LR, Fernandez-Patron C, Hardy E, Huerta $\mathrm{V}$. A procedure for protein elution from reverse-stained polyarcylamide gels applicable at the low picomole level: An alternative route to the preparation of low abundance proteins for microanalysis. Electrophoresis. 1996; 17: 1564-1572.

33. Bradford MM. A rapid and sensitive method for the quantitation of microgram quantities of protein utilizing the principle of protein-dye binding. Anal Biochem. 1976; 72: 248-254.

34. Neuhoff V, Arold N, Taube D, Ehrhardt W. Improved staining of proteins in polyacrylamide gels including isoelectric focusing gels with clear background at nanogram sensitivity using Coomassie Brilliant Blue G-250 and R-250. Electrophoresis. 1988; 9: 255-262.

35. Rao L, Dworkin JD, Nell WE, Bierbach U. Interactions of a platinum-modified perylene derivative with the human telomeric G-quadruplex. J Phys Chem B. 2011; 115: 13701-13712.

36. Feng M. Roles of divalent metal ions in flap endonucleasesubstrate interactions. Nat Struct Mol Biol. 2004; 11: 450-456. 
37. Ge Y, Liu KX, Zhang JX, Mu SZ, Hao XJ. The limonoids and their antitobacco mosaic virus (TMV) activities from Munronia unifoliolata Oliv. J Agric Food Chem. 2012; 60: 4289-4295.

38. Frisch MJ. Gaussian 03, revision B-03. Gaussian, Inc., Pittsburgh, PA. 2003.

39. Sanner MF. A component-based software environment for visualizing large macromolecular assemblies. Structure. 2005, 13: 447-462.

40. Case DA. AMBER 9. University of California, San Francisco. 2006.

41. Singh UC, Kollman PA. An approach to computing electrostatic charges for molecules. J Comput Chem. 1984; 5: 129-145.

42. Besler BH, Merz KM, Kollman PA. Atomic charges derived from semiempirical methods. J Comput Chem. 1990; 11: 431-439.
43. Bayly CI, Cieplak P, Cornell WD, Kollman PA. A wellbehaved electrostatic potential based method using charge restraints for deriving atomic charges: the RESP model. J Phys Chem. 1993; 97: 10269-10280.

44. Cornell WD, Cieplak P, Bayly CI, Kollman PA. Application of RESP charges to calculate conformational energies, hydrogen bond energies, and free energies of solvation. J Am Chem Soc. 1993; 115: 9620-9631.

45. Morishita T. Fluctuation formulas in molecular-dynamics simulations with the weak coupling heat bath. J Chem Phys. 2000; 113: 2976-2982.

46. Darden T, York D, Pedersen L. Particle mesh Ewald: An N. $\log (\mathrm{N})$ method for Ewald sums in large systems. J Chem Phys. 1993; 98: 10089-10092.

47. Song W. Structural basis for specific recognition of singlestranded RNA by Toll-like receptor 13. Nat Struct Mol Biol. 2015; 22: 782-787. 